\title{
PENGARUH PROMOSI TERHADAP KEPUTUSAN KULIAH DI STIE YANG ADA DI KOTA PEKANBARU
}

\author{
Yusriadi \\ Sekolah Tinggi Ilmu Ekonomi Riau \\ Jl. H.R. Subrantas KM 10,5 Panam, Pekanbaru \\ email : yusriadi76@gmail.com \\ diterima: 5/1/2019; direvisi: 31/3/2019; diterbitkan: 24/9/2019
}

\begin{abstract}
This study aims to analyze and test the effect of promotion on college decisions at STIE in the city of Pekanbaru. The sampling technique is done by using purposive sampling technique. The data analysis technique used simple regression with a sample of 42 people who were actively studying at STIE in Pekanbaru City. The results showed that promotion influenced the decision to study at STIE in Pekanbaru. Suggestions in this study, the STIE campus must be able to maintain and enhance promotional activities in getting new students
\end{abstract}

Keywords: Promotion and College Decision

\section{PENDAHULUAN}

Dalam sistem pendidikan nasional kita, perguruan tinggi adalah institusi tertinggi dan ini sama juga hal nya dengan negara-negara lain di dunia. Dalam perspektif peran dan fungsinya, pendidikan tinggi menjadi sangat strategis karena terkait dengan fungsi Tri Dharma, yakni peran melaksanakan pendidikan, penelitian dan pengabdian kepada masyarakat. Untuk itu bagi perguruan tinggi di tuntut untuk mampu menjalankan ketiga fungsi tersebut secara maksimal.

Perguruan tinggi yang menjalankan fungsi Tri Dharma nya dengan baik secara otomatis akan berbanding lurus dengan out put yang di hasilkan yakni dimana lulusannya dapat berkompetisi untuk mengambil peranperan profesional dan strategis di dunia kerja. Ini tentunya menjadi salah satu indikator keberhasilan perguruan tinggi jika lulusan atau alumninya mampu terserap sebanyak-banyaknya di pasar kerja. Suatu perguruan tinggi yang di kenal sebagai kampus yang dapat menghasilkan lulusan berkualitas, maka kampus tersebut akan banyak yang berminat untuk masuk menjadi mahasiswa. Dalam perpekstif manajemen pemasaran, maka perguruan tinggi tersebut sudah mendapatkan suatu promosi yang di lakukan oleh pelanggannya, yakni word of mouth atau pembicaraan dari mulut ke mulut.

Seiring dengan pertumbuhan penduduk yang sangat tinggi dan kesadaran masyarakat untuk memiliki pendidikan tinggi juga semakin meningkat, maka market place calon mahasiswa baru yang akan masuk ke perguruan tinggi semakin besar. Kampuskampus negeri tidak mampu menampung seluruh calon mahasiswa yang ingin kuliah, maka pada saat yang sama, tumbuh suburlah Perguruan Tinggi Swasta (PTS) untuk menjawab kebutuhan pasar. Menurut data wikipiedia (2019) ada sekitar 60 Perguruan Tinggi Swasta dan yang paling fenomenal adalah tumbuhnya secara signifikan sekolah tinggi dan akademi. Untuk di Riau ada 6 Universitas, 1 Lembaga Pendidikan, 23 Sekolah Tinggi, 5 Politeknik dan 25 Akademi. Maka penting bagi perguruan tinggi swasta yang ingin survive harus memiliki kemampuan bersaing untuk merebut calon mahasiswa baru, untuk itu salah satu yang menjadi isunya adalah 
bagaimana melakukan strategi promosi yang efektif.

Menurut Ujang Sumarwan (2011) pada umumnya cukup sulit bagi siswa SMU untuk menentukan pilihan memasuki perguruan tinggi dalam rangka melanjutkan pendidikan. Kesulitan yang di alami para siswa SMU biasanya karena mereka belum tahu secara jelas akan memilih kuliah di jurusan apa. Dengan belum adanya konsep dan gambaran tentang jurusan yang akan diambil dalam kuliah, para siswa cenderung memilih perguruan tinggi yang sudah mereka kenal atau mereka ketahui.

Karena ketidaktahuan atau masih ragu-ragunya jurusan apa yang apa yang akan di pilih oleh para calon mahasiswa baru, maka fungsi melakukan kegiatan promosi menjadi sangat penting di lakukan oleh perguruan tinggi swasta. Hal ini disebabkan maksud dan tujuan kegiatan promosi adalah memberikan pengetahuan terhadap produk yang di tawarkan kepada konsumen sehingga memunculkan kebutuhan yang pada akhirnya ada suatu keputusan pembelian.

Menurut Indriyo Gitosudarmo dalam Danang Sunyuto (2014) menyebutkan promosi sebagai aktivitas untuk mempengaruhi konsumen agar produk yang di tawarkan diminati oleh konsumen. Sedangkan menurut Menurut Wiliam J.Stanton (2007) promotion is the element an orzanizational's marketing mix that serves ti inform, persuade, and remind the market of the organiation and or its products. (Promosi adalah unsur dalam bauran pemasaran perusahaan yang di dayagunakan untuk memberitahukan, membujuk, dan mengingatkan tentang produk perusahaan.

Dalam penelitian ini penulis membatasi hanya untuk perguruan tinggi swasta pada Sekolah Tinggi Ilmu Ilmu Ekonomi (STIE) yang ada di Pekanbaru. Karena setiap kampus tentunya ingin meningkatkan jumlah mahasiswanya, begitu juga bagi kampus STIE yang ada di Pekanbaru. Promosi yang itensif akan berguna untuk memberikan pengetahuan bagi para calon mahasiswa sampai mereka memilih untuk kuliah di kampus STIE. Ada lima kampus STIE yang saat ini masih eksis, yakni STIE Purna Graha Pekanbaru, STIE Dharma Putra Pekanbaru, STIE Persada Bunda Pekanbaru, STIE Riau Pekanbaru dan STIE Pelita Indonesia Pekanbaru.

Dari latar belakang yang sudah di uraikan di atas maka penulis tertarik melakukan suatu penelitian dengan judul "pengaruh promosi terhadap keputusan kuliah di Kampus STIE yang ada di kota Pekanbaru"

Dari latar belakang yang telah diuraikan di atas, maka peneliti merumuskan permasalahannya adalah "apakah promosi berpengaruh terhadap keputusan kuliah di STIE yang ada di kota Pekanbaru"

Adapun tujuan penelitian ini adalah untuk mengetahui pengaruh promosi terhadap keputusan kuliah di STIE yang ada di Kota Pekanbaru

\section{TINJAUAN PUSTAKA}

Menurut Wiliam J.Stanton (2007) pemasaran adalah suatu aktivitas bisnis yang di rancang untuk melakukan kegiatan promosi suatu produk bisa berupa barang atau jasa serta mendistribusikannya kepada konsumen dalam rangka memenuhi keinginan dan kebutuhan pasar sasaran.

$$
\text { Hurriyanti, Ratih }
$$
memberikan pengertian promosi sebagai aktivitas dalam memberikan informasi dengan cara mengedukasi calon konsumen sehingga dapat mempengaruhi dan mengingatkan calon konsumen agar dapat memutuskan untuk melakukan pembelian.

Menurut Kotler dan Armstrong (2008) Secara garis besar adapun jenisjenis kegiatan promosi dapat di uraikan 
Jurnal Ilmiah Ekonomi dan Bisnis

Vol. 16. No.2, September 2019: 168-175

EISSN : $2442-9813$

ISSN : $1829-9822$

sebagai berikut. Pertama adalah advertising (iklan) merupakan aktivitas promosi melalui media cetak maupun elektronik bisa dalam bentuk pemasangan iklan di televisi, radio, dan hal-hal yang berbentuk tercetak seperti brosur, baleho, banner, pamplet dan alinlain.

Kedua, personal selling (penjualan personal) merupakan aktivitas promosi penjualan dengan menggunakan komunikasi yang berbasis person to person yang implementasinya bisa melalui kegiatan presentasi produk atau melakukan pendekatan secara personal dan itensif kepada calon konsumen.

Ketiga, sales promotion (promosi penjualan) merupakan aktivitas pemasaran yang sifatnya melengkapi promosi melalui advertising dan personal selling. Adapun bentuk nya dengan memberikan discount, undian dan hadiah dengan harapan konsumen akan membeli lebih banyak.

Keempat public relation (hubungan masyarakat) merupakan aktivitas menciptakan citra perusahaan atau lembaga (corporate image) yang positif dengan berbagai kegiatan sosial dan amal dengan melakukan konfresni pers atau membuat even-even olah raga dan hiburan kepada customer.

Kelima direct marketing (pemasaran langsung) merupakan kegiatan dalam membangun hubungan secara langsung dengan konsumen baik menggunakan surat, telepon, talk show di televisi, e-mail, Internet, maupun sarana lainnya yang sifatnya direct.

Menurut Schiffman dan Kanuk dalam Sudaryono (2016) keputusan pembelian merupakan tindakan pembelian karena sudah melalui berbagai pertimbangan baik dari dalam diri sendiri (internal) maupun faktorfaktor eksternal atau orang lain. Philip Kotler (1987) menjelaskan bahwa niat pembelian di pengaruhi oleh faktor pendapatan keluarga, harga yang di harapkan dan manfaat yang di dapat.

Hipotesis dalam penelitian adalah di duga promosi memiliki pengaruh terhadap keputusan untuk kuliah di STIE yang ada di Kota Pekanbaru.

\section{METODE PENELITIAN}

Desain dalam penelitian ini bertujuan untuk mengetahui nilai masingmasing variabel, sehingga diketahui nilai variabel yang mempengaruhi dan yang terpengaruh untuk dapat di ambil suatu analisa apakah ada pengaruh antara kedua variabel tersebut.

Populasi dan sampel dalam penelitian ini adalah para mahasiswa Sekolah Tinggi Ilmu Ekonomi (STIE) yang ada di Kota Pekanabru. Pengambilan sampel dengan menggunakan metode sampling insidential yakni memilih sampel secara kebetulan (insidential), atau siapa saja yang kebetulan bertemu dengan peneliti dan dianggap sesuai dengan karakteristik sampel yang ditentukan. Jumlah sampel sebanyak 42 orang, dengan alasan menurut Roscoe dalam Wiratna Sujarweni (2015) menjelaskan bahwa jumlah sampel minimal 30 orang sudah bisa dilakukan di dalam sebuah penelitian.

Teknik dalam mengumpukan data dalam penelitian ini adalah dengan menyebarkan kuesioner (angket) yang di isi oleh responden untuk mengungkap sejauh mana aktivitas promosi berpengaruh terhadap keputusan kuliah di STIE. Peneliti juga melakukan studi pustaka dengan membaca buku-buku serta jurnal penelitian yang sesuai dengan penelitian ini.

Promosi (X) adalah aktivitas dalam memberikan informasi dengan cara mengedukasi calon konsumen sehingga dapat mempengaruhi dan mengingatkan calon konsumen agar dapat memutuskan untuk melakukan pembelian. Adapun bentuk kegiatannya berupa advertising (periklanan), personal selling (penjualan 
pribadi), sales promotion (promosi penjualan), public relations (hubungan masyarakat) dan direct marketing (pemasaran langsung) (Kotler dan Armstrong, 2008)

Keputusan pembelian adalah tindakan pembelian karena sudah melalui pertimbangan baik dari dalam diri sendiri (internal) maupun faktorfaktor dari orang lain (eksternal) atau orang lain (Menurut Schiffman dan Kanuk dalam Sudaryono (2016)

Semua daftar pernyataan yang tertuang dalam kuesioner di uraikan melalui skala likert. Adapun skala distribusi rata-rata jawaban responden dapat dilihat pada tabel berikut :

Tabel 1: Klasifikasi Jawabab

\begin{tabular}{|l|c|}
\hline Klasifikasi Jawaban & Skor \\
\hline Sangat Tidak Setuju (STS) & 1 \\
\hline Tidak Setuju (S) & 2 \\
\hline Cukup Setuju (CS) & 3 \\
\hline Setuju (S) & 4 \\
\hline Sangat Setuju (SS) & 5 \\
\hline
\end{tabular}

Sumber : Sugiyono (2013)

Uji validitas digunakan untuk mengukur valid atau tidaknya suatu instrumen penelitian. Uji validitas di lakukan dengan cara membandingkan hasil $r$ hitung dengan $r$ tabel. Jika hasil nya lebih besar $r$ hitung dari $r$ tabel maka disebut valid (Sugiono, 2013).

Menurut Sugiyono, (2013) uji reliabilitas dalam penelitian dilihat dari hasil nilai koefisien cronbach alpha. Instrumen dikatakan reliable jika memiliki nilai koefisien cronbach alpha sama atau lebih dari 0,6.

Uji normalitas digunakan untuk menguji apakah variabel independen dan dependen nya mempunyai distribusi yang normal. Data di sebut normal jika data menyebar mengikuti arah garis diagonal atau grafik histogramnya.

Dalam metode analisis data ini menggunakan analisis regresi linear sederhana dengan spesifikasi model sebagai berikut : $\mathrm{Y}=\mathrm{a}+\mathrm{bX}+\mathrm{e}$

$$
\begin{aligned}
& \text { Y : Variabel Keputusan Kuliah } \\
& a: \text { Konstanta } \\
& \mathrm{X}: \text { Promosi } \\
& e: \text { Variabel pengganggu }
\end{aligned}
$$

Uji t di lakukan bertujuan untuk mengetahui ada tidaknya pengaruh antara variabel bebas dengan variabel terikat. Untuk mengetahuinya adanya pengaruh atau tidak maka dengan membandingkan nilai $t$ hitung dengan $t$ tabel. Jika $t$ hitung lebih besar dari pada t tabel maka artinya adanya pengaruh variabel bebas kepada variabel terikat.

Koefisien determinasi $\left(\mathrm{R}^{2}\right)$ bertujuan untuk mendapatkan penjelasan berapa persen kontribusi variabel independen mempengaruhi variabel dependen yang dapat dilihat hasilnya di model summary ${ }^{b}$ tertulis $\mathrm{R}$ square. Interfalnya 0 sampai dengan $100 \%$.

\section{HASIL DAN PEMBAHASAN}

Berikut ini adalah hasil uji validitas yang dapat dilihat pada tabel 1 berikut ini:

Tabel 2: Uji Validitas

\begin{tabular}{|l|l|l|l|}
\hline Indikator & R Hitung & R Tabel & Ket \\
\hline X.1 & 0,794 & 0,304 & Valid \\
\hline X.2 & 0,814 & 0,304 & Valid \\
\hline X.3 & 0,494 & 0,304 & Valid \\
\hline X.4 & 0,548 & 0,304 & Valid \\
\hline X.5 & 0,867 & 0,304 & Valid \\
\hline Y.1 & 0,538 & 0,304 & Valid \\
\hline Y.2 & 0,756 & 0,304 & Valid \\
\hline
\end{tabular}

Sumber : Data Olahan 2019

Adapun $\mathrm{r}$ tabel di peroleh dengan mendapatkan nilai $\mathrm{df}=\mathrm{N}$ (Jumlah Sampel) - 4, maka df $=(42)-2=40$, maka $r$ tabel dari angka 40 di tabel $\mathrm{r}$ adalah $=0,304$. Dari data diatas menunjukkan bahwa semua item pernyataan di katakan valid karena hasilnya lebih besar dari 0,304. 
Jurnal Ilmiah Ekonomi dan Bísnís

Vol. 16. No.2, September 2019: 168-175

EISSN : $2442-9813$

ISSN : $1829-9822$

Uji Reliabilitas

Berikut ini adalah hasil dari uji reliabilitas yang dapat dilihat pada tabel 2 berikut ini:

Tabel 3: Hasil Uji Realibilitas

Reliability Statistics

\begin{tabular}{|r|r|}
\hline $\begin{array}{c}\text { Cronbach's } \\
\text { Alpha }\end{array}$ & N of Items \\
\hline, 718 & 7 \\
\hline
\end{tabular}

Sumber : Data Olahan 2019

Berdasarkan data diatas dapat di jelaskan bahwa instrumen penelitian ini realible karena hasil koefisien crobach alpha nya sebesar 0,718 atau lebih besar 0,6 .

Pertanyaan apakah iklan melalui media cetak berupa baleho, spanduk, brosur, banner dll, maupun iklan melalui media elektronik yakni iklan di Riau Televisi (RTV) mempengaruhi responden untuk memutuskan kuliah di STIE yang ada di Kota Pekanbaru. Dari data menunjukkan bahwa iklan (advertising) masih sangat efektif dalam mempengaruhi responden dalam memutuskan kuliah di STIE yang ada di Kota Pekanbaru dengan tingkat persentase sangat setuju $28,6 \%$ dan setuju $54,8 \%$.

Pertanyaan apakah penawaran secara pribadi (personal selling) dari para Marketer STIE yang ada di Kota Pekanbaru mempengaruhi responden untuk memutuskan kuliah di STIE Riau. Dari menunjukkan bahwa pendekatan secara pribadi atau (personal selling) masih sangat efektif dalam mempengaruhi responden dalam memutuskan kuliah di STIE yang ada di Kota Pekanbaru dengan tingkat persentase sangat setuju $21,4 \%$ dan setuju $50 \%$.

Pertanyaan apakah responden memutuskan kuliah di STIE yang ada di Kota Pekanbaru karena adanya discount atau kemudahan lain dari sisi pembayaran (sales promotion). Dari data menunjukkan bahwa sales promotion melalui discount dan kemudahan pemabayaran masih sangat efektif dalam mempengaruhi responden dalam memutuskan kuliah di STIE yang ada di Kota Pekanbaru dengan tingkat persentase sangat setuju 45,2 \% dan setuju 40,5\%.

Pertanyaan apakah penilaian yang baik oleh masyarakat tentang STIE Riau mempengaruhi responden memutuskan kuliah di STIE yang ada di kota Pekanbaru. Dari data menunjukkan bahwa public relation dimana STIE yang ada di Kota Pekanbaru mampu membangun opini yang positif di tengah masyarakat mampu mempengaruhi responden dalam memutuskan kuliah di STIE yang ada di Kota Pekanbaru dengan tingkat persentase sangat setuju 31,7 \% dan setuju 57,1\%.

Pertanyaan apakah responden memutuskan kuliah di STIE yang ada di Kota Pekanbaru karena mendapatkan penawaran secara langsung melaui surat, email, sms atau BC dari WA, BBM, Line, Twitter, FB dan IG. Dari data menunjukkan bahwa direct selling atau penawaran langsung melalui surat, email, sms atau BC dari WA, BBM, Line, Twitter, FB dan IG masih efektif dalam mempengaruhi responden dalam memutuskan kuliah di STIE yang ada di Kota Pekanbaru dengan tingkat persentase sangat setuju $19 \%$ dan setuju 28,6\%.

Pernyataan responden memutuskan sendiri tanpa ada masukan dari orang lain dalam memilih Kuliah di STIE yang ada di Kota Pekanbaru. Dari data menunjukkan bahwa keputusan responden dalam memutuskan kuliah di STIE yang ada di Kota Pekanbaru di pengaruhi atas pengetahuan sendiri cukup besar dengan tingkat persentase sangat setuju $33 \%$ dan setuju $42,9 \%$.

Pernyataan ada faktor pengaruh atau masukan dari orang lain yang menyebabkan responden kuliah di STIE yang ada di Kota Pekanbaru. Dari data 
menunjukkan bahwa keputusan responden dalam memutuskan kuliah di STIE yang ada di Kota Pekanbaru di pengaruhi oleh orang lain juga cukup besar dengan tingkat persentase sangat setuju $38,1 \%$ dan setuju $21,4 \%$.

Dari data rekapitlasi menunjukkan bahwa secara urutan dari persentase terbesar sampai yang terkecil alasan mahasiswa kuliah di STIE yang ada di Kota Pekanbaru karena STIE yang ada di Kota Pekanbaru di nilai masyarakat masih sebagai kampus yang baik (public relation) dengan angka $88,8 \%$. Kemudian karena faktor discount dan kemudahan dari sisi pembayaran (sales promotion) sebesar $85,7 \%$. Berikutnya faktor iklan (advertising) di media cetak maupun elektronik sebesar $83,4 \%$. Untuk faktor pendekatan dari marketer (personal selling) sebesar $71,4 \%$. Sedangkan melalui penjualan langsung (direct marketing) diurutan terakhir dengan angka 47,6\%.

Uji Normalitas Data

Berikut ini gambar yang menunjukkan normalitas data.

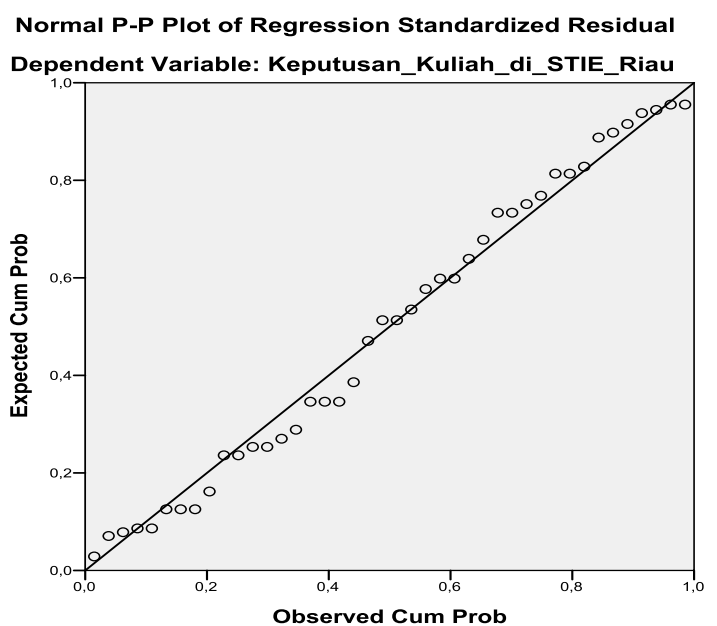

Pada gambar di atas memberikan suatu penjelasan bahwa instrumen dalam penelitian ini memenuhi syarat normal dimana probability plot nya berdistribusi normal dengan titik-titiknya mengikuti arah garis diagonalnya.
Analisis Regresi Linear Sederhana

Hasil pengolahan data melalui analisis regresi linerar sederhana.

Tabel 4: Hasil Uji t

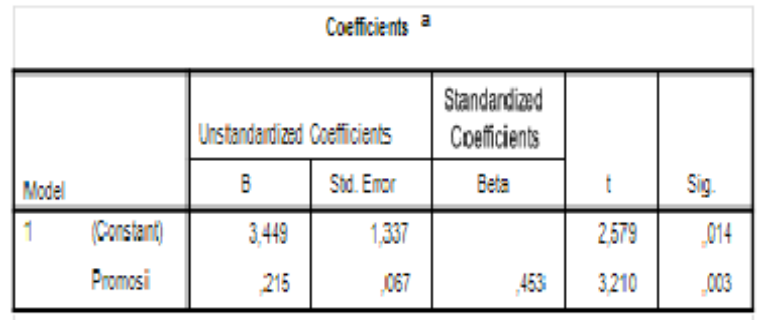

8. Dependent Vanable: Keputusan_Kulliah_di_STE.

Berdasarkan tabel diatas diperoleh nilai persamaan regresi linear sederhana yaitu : $\mathrm{Y}=3,449+0,215 \mathrm{X}$. Adapun interperstasinya adalah jika promosi tidak di lakukan atau bernilai nol, maka keputusan calon mahasiswa untuk kuliah di STIE yang ada di Pekanbaru sebesar 3,449 .

Tabel 5 : Uji Determinasi

$$
\text { Model Summary }
$$

\begin{tabular}{|l|c|r|r|r|}
\hline Model & $R$ & $R$ Square & $\begin{array}{c}\text { Adjusted } R \\
\text { Square }\end{array}$ & $\begin{array}{c}\text { Std. Error of } \\
\text { the Estimate }\end{array}$ \\
\hline 1 &, $453^{\mathrm{a}}$ &, 205 &, 185 & 1,32999 \\
\hline
\end{tabular}

a. Predictors: (Constant), Promasi

b. Dependent Variable: Keputusan_Kuliah_di_STIE_

Dari hasil diatas nilai koefisien determinasi yang di sesuaikan ( $R$ Square) adalah sebesar 0,205 atau sebesar 20,5\%. Hal ini menjelaskan bahwa promosi berkontribusi sebesar 20,5 \% dalam mempengaruhi konsumen untuk memutuskan kuliah di STIE, sedangkan sisanya sebesar $(100 \%-20,5 \%)=79,5$ $\%$ di jelaskan oleh faktor lainnya di luar dari variabel promosi.

Untuk mendapatkan jawaban apakah promosi (variabel X) berpengaruh terhadap Keputusan Kuliah (varibel Y) maka dilakukan uji $\mathrm{t}$ dengan menggunakan analisis regresi linear sederhana. Penentuan hasil pengujian 


\section{Jurnal Ilmiah Ekonomi dan Bisnis}

Vol. 16. No.2, September 2019: 168-175

EISSN : $2442-9813$

ISSN : $1829-9822$

dilakukan dengan membandingkan thitung dengan t-tabel. Adapun nilai $t$ tabel dari penelitian ini adalah nilai df sebesar $(\mathrm{n}-\mathrm{k})$, dimana $\mathrm{n}=$ jumlah sampel dan $\mathrm{k}=$ jumlah variabel, maka hasilnya $(42-2=40)$. Dalam t tabel angka 40 dengan tingkat signifikansi 0.05 adalah sebesar 2,021.

Hasil uji $t$ antara variabel promosi sebagai variabel independen terhadap variabel keputusan kuliah di STIE yang ada di Kota Pekanbaru sebagai variabel dependen, hasil nya adalah nilai t hitungnya sebesar 3,210. Dengan nilai t tabel sebesar 2,021, maka nilai t hitung lebih besar dari pada nilai $t$ tabel. Sedangkan nilai signifikansi sebesar 0,003 yakni lebih kecil dari pada 0,05 . Dengan demikian dapat di jelaskan bahwa promosi berpengaruh positif dan signifikan terhadap Keputusan Kuliah di STIE yang ada di Kota Pekanbaru.

Dengan demikian promosi yang dilakukan oleh pihak STIE yang ada di Kota Pekanbaru yakni berupa advertising, personal selling, public relation, sales promotion dan direct marketing memberikan pengaruh terhadap keputusan calon mahasiswa untuk kuliah di STIE yang ada di Kota Pekanbaru.

\section{KESIMPULAN DAN SARAN}

Dari hasil analisis deskriptif dapat diambil kesimpulan bahwa faktor public relation, sales promotion dan advertising menjadi alasan terkuat mengapa mahasiswa memutuskan kuliah di STIE yang ada di Kota Pekanbaru. Berikutnya menyusul faktor personal selling dan direct marketing. Dari hasil uji t melalui analisis regresi linear sederhana dapat simpulkan bahwa promosi berpengaruh positif dan signifikan terhadap keputusan kuliah di STIE yang ada di Kota Pekanbaru dengan $t$ hitung sebesar 3,210 lebih besar dari t tabel sebesar 2,021 dan nilai signifikansi sebesar 0,003 lebih kecil dari 0,05 .
Hipotesis dalam penelitian ini dapat di terima, dimana promosi berpengaruh positif dan signifikan terhadap keputusan kuliah di STIE yang ada di Kota Pekanbaru.

Saran yang dapat diberikan yakni tetap mempertahankan dan menjaga nama baik kampus, terus menerapkan strategi discount dan kemudahan dalam sistem pembayaran kuliah. Memperbanyak iklan baik di media cetak maupun elektronik. Meningkatkan kemampuan tenaga pemasar (marketing) dalam melakukan pendekatan kepada calon mahasiswa. Memaksimalkan sarana email dan media sosial lainnya dalam melakukan penawaran langsung kepada calon mahasiswa.

\section{DAFTAR PUSTAKA}

Fandy, Tjiptono (2015). Starategi Pemasaran. Penerbit Andi. Yogyakarta

Hurriyati, Ratih (2015). Bauran Pemasaran Dan Loyalitas Konsumen. Alfabeta, Cv. Bandung.

Indriyo Gitosudarmo (1999). Manajemen Pemasaran, cetakan 5. Penerbit BPFE : Yogyakarta.

Kotler, Philip dalam Drs. Danang Sunyoto, SH, SE, MM, 2014, Dasar-dasar Manajemen Pemasaran, Konsep, Strategi dan Kasus, Edisi Ke Tiga, CAPS

Kotler, Philip dan Gary, Armstrong. 2008. Prinsip-prinsip Pemasaran. Jakarta : Erlangga

Kotler, Philip, (1987) Principle Marketing, Third Edition, PT.Midas Surya Grafindo. Jakarta.

Mursid, M (2014). Manajemen Pemasaran. PT Bumi Angkasa. Jakarta Philip Kolter dan Amstrong (2009). 
Manajemen

Pemasaran.

Erlangga. Jakarta.

Sudaryono (2016). Manjemen Pemasaran.

Penerbit Andi. Yogyakarta

Sugiono (2009). Statistic Untuk Penelitian. Alfabeta. Bandung

Sunyoto, Danang (2014). Dasar-Dasar Manajemen Pemasaran. Penerbit CAPS Yogyakarta.

Ujang Sumarwan (2011) Perilaku

Konsumen: Teori dan

Penerapannya dalam Pemasaran.

Bogor : Ghalia Indonesia

Wiliam J.Stanton, Michael J.Etzel \& Bruce J.Walker (2007). DasarDasar Manajemen Pemasaran, cetakan 1. Penerbit Mandar maju : Bandung.

V.Wiratna Sujarweni, 2015, Metedologi Penelitian, Yogyakarta, Pustaka Baru Press. 